\title{
The Rebellion against God: Emily Dickinson's Influence on Allen Ginsberg
}

\author{
Rima Bhattacharya \\ Department of Humanities and Social Science, Indian Institute of Technology, Kharagpur, India
}

\begin{abstract}
This paper draws a comparison between two American poets, Emily Dickinson and Allen Ginsberg who were not only separated from each other by a century but also belonged to different gender groups. Inspired by the notion of transcendentalism both these poets encouraged humans to indulge in a healthy level of doubt and scepticism, but not to the point of nihilistic despair. They searched for hope within another source the human body comprising of a pure soul, which itself according to them, always contains a spark of divinity. They indulged in the debunking of the flowery promises of heaven, resurrection and an after-life and insisted on living a zestful life on earth. They felt that there was no need for any intercession in the relationship between man and God. Both of them rebelled against the external figure of a deity or God in order to free mankind from organized religion and restore the faith of mankind on the unlimited potential of human ability to connect with both the natural and the spiritual world.
\end{abstract}

Keywords: Dickinson, Doubt, Faith, God, Ginsberg, Howl, Kaddish, Transcendentalism

\section{Introduction}

Transcendentalism as a philosophical movement developed in the 1830s and 1840s in the Eastern region of the United States as a protest to the general state of culture and society. The transcendentalists firmly believed the inherent goodness of both man and nature. Transcendentalists believed that society, its institutions and organized religion ultimately corrupted the purity of the individual. They had faith that man is at his best when truly self-reliant and independent. It is only from such confident and hardworking individuals that true community could be formed. Transcendentalism was in many aspects the first notable American intellectual movement. It was certainly one of the first movements to inspire succeeding generations of American intellectuals, as well as a number of literary monuments.

Rooted in the transcendental philosophy of Immanuel Kant and of German Idealism it developed as a reaction against 18th Century rationalism. Emerson believed that all things are connected to God and, therefore, all things are divine. Emerson was partly influenced by German philosophy and Biblical criticism. His views, the basis of Transcendentalism, suggested that God does not have to reveal himself as the truth but that the truth could be intuitively experienced directly from nature. The publication of Ralph Waldo Emerson's 1836 essay Nature is usually considered to be one his seminal productions which inspired transcendentalism to gather force as a major cultural movement. Probably the most important ingredient of American ideology is its belief in the freedom of the individual (called "individualism" for short). The fundamental essence of each individual has been divinely created and inspired, Emerson declared (See Churchyard). Emerson was drastic in his conviction that an individual should obey himself and himself alone: "What I must do is all that concerns me, not what the people think.... I shun father and mother and wife and brother when my genius calls me" (Emerson 2005: 117).

The poet Emily Dickinson, who published few poems during her lifetime was highly influenced by Ralph Waldo Emerson and was a friend of later transcendentalist T. W. Higginson. She frequently voices ideas of independence and individualism, of reaction against conformity and obeisance to tradition, providing us a poetic variation upon the theme of self-reliance. Her lyrics are her highly subjective. One-fifth of them begin with "I". Emily's theological orientation was Puritan and she was taught all the premises of Calvinistic dogma, but she reacted strenuously against two of them: infant damnation and God's sovereign election of His own. Another force alive in her time that competed for her interests was the force of literary transcendentalism. This explains her paradoxical or ambivalent attitude toward matters of religion. She loved to speak of a compassionate saviour and the grandeur of the Scriptures, but she disliked the hypocrisy and arbitrariness of institutional church (See Reuben). Emily's preference for individualism and her spirit of transcendentalism were also seen among the existentialists, who began by negation, refusing to accept the social given. The existentialists and later the Beats agreed with the dictum of transcendentalism, that man defines himself through his actions. A nineteenth century poetess, Emily's philosophy that upheld the sanctity of the individual, was also accepted by the twentieth century beat poet Allen Ginsberg and a lost generation of the twenties who were inculcated with the post-war values that accepted man as the victim of circumstances and no longer granted him the agency of his own destiny. 


\section{A Comparison: A Common Quest For The Shrouded Stranger}

In his 1794 book The Age of Reason, Thomas Paine advanced a religious philosophy called Deism that struck at the roots of organized religions, particularly Calvinism as it was practiced by the Puritans. According to Paine, churches were set up to terrify and enslave mankind, and monopolize power and profit (See Aboukhadijeh 2012). These thoughts were shocking to Americans who were imbued with a strong religious tradition. At the same time, Paine's ideas appealed to many Americans who were likewise disillusioned in the rationality of the Enlightenment period and who had difficulty aligning Calvinist doctrine with reason. These newly introduced ideas did cast a shadow of doubt on the figure of the Almighty or an external deity. The shadows of doubt are clearly discernable in many of Emily's poems:

I know that He exists.

Somewhere - in Silence -

He has hid his rare life

From our gross eyes. (The Poems of Emily Dickinson 270)

The concepts of Crucifixion and Resurrection have offered different problems of faith to different ages of Christianity. In the earliest days of the church, the Resurrection was nothing extraordinary to believe, for Christ was God, and God could surely rise from the dead and ascend into Heaven. In the modern age, although the fact of Christ's death gains acceptance, his Resurrection confounds faith. In other words, this observation can be usefully applied to distinguish between the early days of American Puritanism and that point in the nineteenth or early twentieth century when a disenchanted land began to repose its faith in the power of the dynamo.

In traditional Christianity, mankind's first sin provides the defining category for the human condition. Humans are a "fallen" race, a "postlapsarian" breed. Yet Dickinson had other criteria to assess this state. The world her gaze fell upon was replete with the consequences of divine power. If she had submitted to conversion, her vision of that world would have been "adjusted", and she would have discerned evidences of Christ's promises throughout the universe. Yet she did not submit. After 1856, when Austin submitted to conversion, all the other members of Emily Dickinson's family had professed their confidence in the promises of Christ and the new birth to come (See Gelpi, 33). For the poet, however, the fact that she could never glimpse the Face behind the veil made even the process of assigning a name to God problematic. How does one name an absence, she thought and wrote with bitter irony, "Which from it's solemn abbeys/ Such resurrection pours" (The Poems of Emily Dickinson 10).

Dickinson did not assent, even reluctantly, to God's dominion; therefore her poetry can be set apart from the great tradition of religious lyric. Traditionally, the religious poet s had the image of being an inevitable subordinate to God. He might discover cunning new devices for singing God's grandeur, or he might dare to chant of God's darker and more frightening aspect, or he might even inspire people in resisting the rigors of God's discipline. Yet in all of these attitudes, God's essence lies beyond mankind's reach. The poet is unable to compel God to engage in discourse; he can capture God only insofar as God chooses to reveal Himself or to make the poet His instrument. Dickinson was content with none of these premises for poetry (Wolff 1988: 147). Instead one can say that Dickinson's hero-poet is a rebel figure. This poet believes that just as words can be used as the force to bind us to God, they have as well the capacity to break those bonds. The poet can wreak vengeance upon the Deity by exposing His false promises and reanalysing the transcendent meaning of the world so as to reveal the true relationship between the Lord and His subjects. By this prodigious act of usurpation, the poet will challenge God's claim to sovereignty.

Dickinson's achievement was paradoxically a fusion of infinity and nothingness. She invented a new vernacular of "No". The voice of "no" is more than merely an aesthetic achievement; it can articulate a form of release. If one is not frightened of death or suffering, if one can tolerate loss and retain personal integrity, if one is utterly unmoved by the promise of some heaven to come- then God has no hold upon that person. In the same manner, if one disdains the celebrity of public office and the wealth of kings, then one can have the power to be sufficient entirely in oneself (Wolff 1988: 192). According to Dickinson, this was freedom and the only "salvation" available to humans.

Dickinson almost deconstructed the idea of "Divinity" through her poetry. Dickinson's cryptic utterance to Higginson at the beginning of their correspondence, "My Business is Circumference", proves this (The Letters of Emily Dickinson 387). This comment has fascinated and puzzled many of her readers. Charles Anderson rightly cites the Religio Medici of Sir Thomas Browne as the principal source for her remark: "In his effort to define (circumference) as a sense of boundlessness radiating out from a centre, opposite to the normal sense of a limiting circle, (Browne) cited the formulation of Hermes: The Sphere of which the centre is everywhere, the circumference nowhere ... (Dickinson) expanded it into a symbol for all that is outside. Her centre is the enquiring mind whose business is circumference, intent upon exploring the whole infinity of the universe that lies before her". Sensing Dickinson's ambition, Anderson concludes: "The most startling use of the 
term occurs in a late letter: "The Bible dealt with the Centre, not with the Circumference". When set beside her own boast, 'My Business is Circumference', this seemed to be blasphemous. (Anderson 1960: 55-57)

Dickinson through her poems almost attempts an immediate leap into God, which would seem impossible to the ordinary man. Man must go back to the earth, the human experience of pain and suffering, and work out from there towards the divine reality. Dickinson, on the other hand would answer that the poet can leap into God's realm. So long as God cares to demand the obedience and worship of mankind, He is ensnared in the very "Design" that seems to separate the finite world from His realm of infinity and eternity. And insofar as she can locate the crucial areas where God's majesty requires mankind's cooperation, the poet can accomplish something The Bible does not: she can repossess language, using it to expose God's tyranny. The audacity of Dickinson's enterprise reflects the absorbing ideas of the existentialist philosopher Jean Paul Sartre. Towards the end of L'etreet le neant Sartre argues that it is man's basic wish to fuse his openness and freedom with the impermeability of things, to achieve a state of being in which the en-soi and pour-soi are synthesized (Kaufmann 1975: 47). This ideal, says Sartre, one can call God, and "man is the being who wants to be God". The chapter ends: "But the idea of God is contradictory... man is a useless passion" (Kaufmann 1975: 47).

Unlike the earliest American Puritans, unlike even the conservative proclaimers of faith in her own generation, Dickinson could not believe in the promises of the Resurrection. Early life had made trust too difficult and Dickinson dismissed prayer as an act of desperation. On the whole, she was inclined to believe in the evidence of things seen, and the realities she confronted were uniformly disillusioning. Jesus had assured humans of personal care from a loving God, but life offered a parade of unalleviated sorrows:

Of Course - I prayed -

And did God Care?

He cared as much as on the Air

A Bird - had stamped her foot - (The Poems of Emily Dickinson 299)

Jesus had promised, "Ask, and it shall be given you"; but even modest requests, prayerfully framed, bring nothing except empty silence: "I have a King, who does not speak". The only reason for which one has to believe in a Resurrection that will vanquish death is the promise of the Man who called himself the "Christ". Yet if all his other promises have proven false, there is compelling reason to suppose that the anticipation of rising in triumphant body is no more than a fool's hope:

I'm glad I don't believe it

For it w'd stop my breath -

And I'd like to look a little more

At such a curious Earth! (The Poems of Emily Dickinson 64)

Dickinson's poetry was founded on the conviction that a genuinely religious poet would have to grapple earnestly with faith by matching Christ's fable and the promises in it against the evidence offered by the visible world. The fruit of her struggle would be an independent song of truth, even when the truth was terrible to hear. Repeatedly Dickinson's poetry returns to the visual image of faith. Sometimes she renders it as a "Pierless Bridge"; sometimes a bridge with "brittle piers". At times the emblematic bridge of faith is transformed by the horror of the moment in a proleptic poem when consciousness begins to fail:

And I dropped down, and down

And hit a world, at every plunge

And finished knowing - then- (The Poems of Emily Dickinson 200)

In Holmes and Barber's Religious Allegories (1848), there is an emblem called "WALKING BY FAITH". It depicts a man, just starting from what appears to be solid ground, to walk upon a narrow plank (with the word 'FAITH' imprinted on it), stretched across a deep "gulph", which ends nobody knows where. On one side is life, and on the other is Heaven and only the plank of "FAITH" can provide transport. Yet having renounced faith, Dickinson substitutes a "Plank in Reason", which breaks because no rational explanation can be adequate to bridge the abyss between earth and Heaven. The poem concludes with a fall that is an apotheosis of confusion (Wolff 1988: 230). One can easily relate this thought of Dickinson to the nineteenth century questioning of religion and the meaning or existence of God by the Danish thinker Kierkegaard and the German philosopher Nietzsche. The former was a devout believer but realized most acutely - as he describes in his book "Fear and Trembling" - that the divinity and its" will are ultimately unknowable to human consciousness and that the Christian must therefore make an irrational and frightening choice, "a leap of faith", in order to maintain his or her belief. In Dickinson one would find "a precarious convergence between her inner experience and her religious inheritance" (Farr 1995: 105). It was the blood rite of the Crucifixion and not the glory of the Resurrection that cast its decisive shadow over Dickinson's poetry. Sometimes the poet seems to have derived a modicum of hope from Jesus' death:

Jesus! Thy crucifix

Enable thee to guess

The smaller size! 
Jesus! Thy second face. (The Poems of Emily Dickinson 161)

For once Dickinson feels, that in Christian theology, Christ, the Son of God, softens the image of his forbidding Father. In the tradition of female mysticism Dickinson at times, identifies with Christ (McNeil 1986: 60-61). Yet more often the desire to accept faith was confounded by the imponderable mystery of God's demise:

The World is not Conclusion.

A Sequel stands beyond -

It beckons, and it baffles -

Philosophy - don't know -

And through a Riddle, at the last - (The Poems of Emily Dickinson 384)

Although the poem begins with an assertion that seems clear, it goes on further to examine the leakage and finally the loss of faith. Dickinson realizes that the essence of conversion experience, the events of the Old Testament, even the promises of Christ, all bear the subtle imprints of deceit, corruption and annihilation. The abstract pattern of all human life spells a message of divine sadism. Dickinson found that the "Narcotics" of the sentimentalized religion could dull one's awareness of the constant peril in life, but could never cure the condition of one's being. In turn, Dickinson exposes the bestial blood -lust of a God Who required the execution of His blameless Son by the means of Crucifixion.

The fable of mankind's first fall and the subsequent drama of sin and guilt did not catch hold of Dickinson's imagination and the word "fall" is seldom employed in her poetry. Yet a similar word, "drop" resounds with implication in her poetry. God courts us with the promise of a splendid afterlife, yet the winning of this prize requires the yielding of identity through conversion or death. Such are the terms by which "faith" and "conversion" have been defined. In seeking to dramatize the plight of one caught between the allure and danger of this dilemma, Dickinson employed a different use of the word "drop":

The Drop, that wrestles in the Sea -

Forgets her own locality -

As I - towards Thee - (The Poems of Emily Dickinson 203)

The 'I' and 'Thee' are mortal woman and possessive God respectively; the "Drop" is a Christian who has already won faith, and the "Sea" is the primordial power of the Divinity. The notion of the "Drop" is useful here primarily because its identity is unstable, dilating and finally dissolving when it touches a larger body of water; and the complex terms of the conflict are predicted upon this notion. Because the "Drop" is "in" the Sea, it has no independent form or identity; it has altogether merged with the water in which it is immersed. Forgetting its "locality", it then strives for freedom. Dickinson believed that If God was truly infinite, then He would need no "Drop", for infinity plus any increment. Divinity cannot be glorified or altered in any way by the acquisition of one small soul (Wolff 1988: 271). It follows from this premise that an infinite God ought not to mind the loss of a single "Drop" or a single soul that wants to be.

Dickinson sometimes calls our attention to the monstrosity of the bride-of-Christ myth by expressing the sexual elements of divine wooing in explicit perverse terms. If God seemed to be unbearably cold and death seemed to be unbearably hard, then in Jesus Dickinson could discover a warm and a gracious side to divinity. However at certain points Dickinson even despaired of Jesus fearing that he too might become silent and distant like his heavenly Father (Lundin 2004: 177) :

God is a distant - stately Lover

Woos, as He stares us -by His Son -

Verily, a Vicarious Courtship - (The Poems of Emily Dickinson 284)

It is a barbaric courtship where the bridegroom promised a Heaven and a place for the bride in this kingdom to come. Yet, to win the bride's place in the hereafter, one must relinquish autonomy and reason, the core of identity in the world that we know, to faith. And after everything, all must pay the price of death, even though Jesus Himself had acknowledged that not all would gain Heaven:

What would I give to see his face?

I'd give - I'd give my life - of course -

But that is not enough! (The Poems of Emily Dickinson 177)

There is something perverse about God's insistence that He must woo us through death. Death is personified as a person whom Emily knew and trusted. The terror of death is objectified through the figure of a genteel driver to would ironically fetch us to the end of immortality (Tandon and Trivedi 2008: 97). God is patient and is willing to wait but if one cannot come conveniently, He will courteously send his own carriage to fetch the person:

Because I could not stop for Death -

He kindly stopped for me -

The Carriage held but just Ourselves - 
And Immortality. (The Poems of Emily Dickinson 546)

Some other poems of Dickinson examine the notion of 'Heaven' with rigor and tries to achieve some comprehensive understanding of the Almighty Being Who waits to receive us after death. In order to do so she had to trace back its roots in the Bible, in Dante, and in Milton's epic vision. Occasionally Dickinson toyed with the simple and seemingly accessible notions that the Scriptures had offered - the palace of God as a well appointed Victorian home with parlours, shut by day. Yet the earthly resting place of those whom God had already called to His bosom left so powerful a vision of the grave, that death and the cemetery obscured the comforting image of Heaven-as-home (Wolff 1988: 323). The Bible also suggests that Heaven can be described as a shining city. Dickinson wonders whether the golden city in the sky would be as familiar as the township of Amherst:

What is - 'Paradise'-

Who live there -

Are they 'Farmers' -

Do they 'hoe' - ... (The Poems of Emily Dickinson 150)

Dickinson through her poetry questions that if Heaven is essentially the same as earth, why must there be the fearful interruption of death. Why would then a benevolent God subject His creatures to such pain and uncertainty. Under these conditions, Dickinson was more than willing to trade the Heaven to come for the vivid life on earth she already knew. Repeatedly, both in letters and in the poetry, she affirmed that life, with its admixture of pain, which accentuates pleasure, offers everything we need of Heaven:

Of Heaven above the firmest proof

We fundamental know

Except for it's marauding Hand

It had been Heaven below. (The Poems of Emily Dickinson 838)

Dickinson finds that like God and like Death, Heaven is also hidden from Humans. Heaven can never be experienced during life. Nonetheless, every human being is constrained to try and imagine what Heaven is like, for it offers the only hope of existence after our time on earth has passed. However even the notion of Paradise as an ultimate resting place can become horrific, if humans enter into that state in which the silence of the hidden God is never broken:

The Flesh - surrendered - Cancelled -

The Bodiless - begun -

Two Worlds - like Audiences - disperse -

And leave the Soul - alone --... (The Poems of Emily Dickinson 402)

A Christian's meditation upon Heaven can go through several stages. Initially, the prospect may seem almost too good to be true:

'Tis so much joy!' Tis so much joy!

If I should fail, what poverty! (The Poems of Emily Dickinson 126)

The question of what a person would be when he or she had sold the self entirely to God was left unasked, and Dickinson sometimes considered this question to be extremely important. The poet often wondered whether anyone who has relinquished will and autonomy be left in a condition to appreciate Paradise or God's presence in it. The focus of this query is not so much upon Heaven, as upon the personal integrity of a human being who has surrendered autonomy to purchase celestial life (Wolff 1988: 333):

He put the Belt around my life -

I heard the Buckle snap -

And turned away, imperial,

My Lifetime folding up --... (The Poems of Emily Dickinson 194)

Dickinson's struggle with God often reminds us of the Biblical figure, Jacob. By Emily Dickinson's time, the model of Jacob had acquired new emphasis. In order to understand the vision of the universe that impelled Dickinson to the vocation of poet, one must understand Jacob's wrestle as Emily Dickinson understood it. In surprising and uncanny ways, this archetype even echoed elements central to her own personal experience. For Dickinson Jacob's legend signified the beginning of a heroic act for those who pursued the heroic quest of wrestling with the word and creating, just as God had created. Jacob the wrestler was a model for the "poet pugilist" (Wolff 1988: 151):

A little East of Jordan,

Evangelists record,

A Gymnast and an Angel

Did wrestle long and hard --... (The Poems of Emily Dickinson 44)

Dickinson's creative imagination was not the only one to be captivated by the power and subtlety of Jacob's story. Melville realized that this archetypal struggle between man and God was pregnant with possible meanings, and so this restive hero from Genesis appears over and over again in Melville's work (Wolff 1988: 
146). Both in the works of Melville and Dickinson one would easily find some Emersonian allusions (See D'Avanzo 1972). Emerson called the poet a "namer", and Dickinson's understanding of such a role was almost certainly reinforced by this assertion in his widely read essay "The Poet", in which the poet is claimed to be a 'representative'. Emerson writes: "He (the poet) stands among partial men for the complete man, and apprises us not of his wealth, but of the common wealth...He is isolated among his contemporaries by truth and his art, but with this consolation in his pursuits, that they will draw all men sooner or later. For all men live by truth and stand in need of expression" (Wolff 1988: 141).Dickinson depicted almost a Protestant tendency in her effort to shift the centre of God's activity from the world outside the self to the spiritual world within it. In doing so, she discovered both the greatness and the wretchedness of humanity (Lundin 2004: 5). Dickinson's quarrel with God reflects the full panoply of human disaffection. Although Dickinson's God rarely seems to make her happy, she never breaks off the affair. She seems to have this idea that no matter how incompatible they may be, human and divine are made for each other (Bloom 2008: 202). A similar kind of discovery was made by another great poet, several years later, after travelling through various parts of the world in search of true divinity and peace. Although Dickinson was one of the first to trace the trajectory of God's decline, many years later, Allen Ginsberg contributed to the same thought- process through his poetry.

A new way of thinking or philosophy originated when at the turn of the nineteenth century people felt a need to balance reason and calculation with emotion and spirit. The German philosopher Immanuel Kant first expressed his doubts regarding rationality which according to him failed to be a medicine for all human problems and needs. In his Critique of Pure Reason, published in 1781 he voices his opinions. Sympathetic poets and authors like Wordsworth, Coleridge, Shelley, Keats, and Tennyson transmuted his ideas into their literary works. The Romantics revered nature and felt that contemplation of natural scenes would lead to realization of fundamental truths.

In America, Emerson and Thoreau helped to transform the Romantic Movement into Transcendentalism, a philosophy that reads almost like a faith. The Transcendentalists infused the Romantic impulse with mysticism, a belief in the possibility of direct communion with God and knowledge of ultimate reality through spiritual insight. In part, this was fuelled by newly translated Hindu, Buddhist, and Islamic texts, which contained elements of mysticism. Dickinson as well as the transcendentalists in general believed in an Inner Light present within the human form that at times expressed itself as divine intuition or knowledge unaccountable by ordinary derivations of thought (See Aboukhadijeh 2012). Allen Ginsberg and his friends, who were collectively known as the Beat Generation, were highly influenced by this new vision of Religion in general and almost all of them had searched for this Inner Light at some point of time, in their respective ways. Like any spiritual innovation, this new vision included a rejection of dominant spiritual norms and established religious institutions.

For the three friends, Kerouac, Ginsberg, and Burroughs, neither positive thinking nor evangelical Christianity could make sense of God's apparent disappearance from the world. But somehow Oswald Spengler's The Decline of the West, a book the beats studied and discussed in the late 1940s, could. After the enormous success of his novel On the Road, Kerouac became a major media attraction. Asked by a television interviewer about what he was looking for, Kerouac's unhesitating reply was "God. I want God to show me his face" (Krim 1960: 14). Kerouac had quit attending mass in his high school and with growing age he went further drifted away from the formal religious teachings of the church and began his search for a source that would fill up the religious void of his life. Kerouac pursued wisdom on his own and created a new canon (The Scripture of the Golden Eternity) for himself but Ginsberg accepted some outside help and travelled to India in search of a guru where he met ChogyamTrungpa, who became his spiritual advisor (Jackson 1988: 63). The beats' retreat from the practiced religion of the churches and synagogues to city streets inhabited by whores and junkies, hobos and jazzmen never ceased to be a search for something to believe in, something to go by. From the perspective of Religionswissenschaft, the beats shared much with pilgrims coursing their way to the world's sacred shrines. Like pilgrims to Lourdes or Mecca, the beats were figures who expressed their cultural marginality by living spontaneously, dressing like bums, sharing their property, celebrating nakedness and sexuality, seeking mystical awareness through drugs and meditation, acting like "Zen lunatics" or holy fools, and perhaps above all stressing the chaotic oneness of human interrelatedness or communities over the pragmatic functionality of social structure (Prothero 1991: 210). With reference to the Beat concept of being a "Zen lunatic" or a holy fool, one is reminded of a famous poem by Dickinson where she writes, "Much madness is divinest sense", indicating that her divine sense might often look like madness to others (McNeil 1986: 16).

When Ginsberg experienced his Blake vision in a New York tenement, he crawled out on a fire escape, rapped on the window of a neighbouring apartment, and screamed, "I have seen God!". He often refers to God in his early poetry, but the precise character of his deity is usually clouded in ambiguity. When Blake spoke to him, "It was like God had a human voice... Or that God was in front of my eyes - existence itself was God". The general impression one gets is that "God" is an imminent kind of depth - dimension who is accessible through "cosmic consciousness" (Clark 1966: 38-39). His residence is definitely in this world because cosmic 
consciousness reveals "The world is holy!...Everyman's an angel!" (Collected Poems 134). Cosmic consciousness confirms that there is but one world and it is absolute, holy and eternal:

This is the one and only

Firmament; therefore

It is the absolute world.

There is no other world.

The circle is complete.

I am living in Eternity.

The ways of this world

Are the ways of Heaven. (Collected Poems 33)

Thus like Dickinson, Ginsberg rejects the idea of heaven outright and confirms that the world and life on earth equals eternity. Worldly existence is the only kind of existence human beings will ever know. There is a constant tension in beat literature, therefore, between misery and splendour, between an overwhelming sadness and an overcoming joy. In the beat cosmos, God is both absent and everywhere. Despite the apparent holiness of all human experience, God also appeared to Ginsberg in frightening forms.

Ginsberg's death theme, particularly his fear of death, is a "major motif" in many of his poems. "Death, Cannot Reach What is Most Near" opens with what appears to be a conundrum:

We know all about death that

We will ever know because

We have all experienced

The state before birth. (Collected Poems 34)

Because there is no cognition before birth, one might assume that we know nothing of death. But if the world is absolute, holy, and eternal, death is simply a name for one state of being in that world. Therefore initially Ginsberg was troubled by the thought that people may in life be imprisoned in "self - consciousness", but in death find a liberation to eternal "cosmic consciousness". Along with this preoccupation with America's decadence, the theme of individual suffering and death looms in beat writing. The beats devoted their lives and their literature to understanding and explicating the private hells of those who remained on the margins of postwar prosperity. Much of Ginsberg's work, including "Howl" and "Kaddish," explores madness and death. Much of the power of Kaddish is generated by the powerful engines of doubt that roar through Ginsberg's memory to the final conclusion that "What came is gone forever every time" (Collected Poems 210). Ginsberg is suspicious of any kind of hope very early in the poem:

To go where? In that Dark - that - in God?a radiance? A Lord in the Void?

Like an eye in the black cloud in a dream? Adonoi at last, with you?

Beyond my remembrance! Incapable to guess! Not merely the yellow skull

In the grave, or a box of worm dust, and a stained ribbon - Deathshead

With Halo? Can you believe it? (Collected Poems 211)

An afterthought on the poem "Kaddish" reflects the shift that had come about in Ginsberg's philosophical posture in Asia during the year documented in "The Change". Describing the state of mind he was in prior to "The Change", Ginsberg has said that "the psychic problem that I had found myself in was that for various reasons it had seemed to me at one time or another that the best thing to do was to drop dead. Or not be afraid of death but go into death. Go into the non- human, go into the cosmic so to speak; that God was death, and if I wanted to attain God I had to die (Clark 1966: 49)".

Several other poems, like Magic Psalm, The Reply and The End belonging to the collection Kaddish and Other Poems, record visions experienced after drinking Ayahuasca, an Amazon spiritual potion. Such an attempt was again made by Ginsberg in order to analyze the true nature of divinity. In order to examine this intensely personal experience of Ginsberg, one might go through his highly allegorical poem, "The Lion for Real". A frightening dimension of divinity is confronted and theologically the experience falls under the Judeo Christian concept of the "wrath of God" (Merrill 1988: 79). Ginsberg's poem contains no petition to the "Terrible Presence" other than the appeal to do his worst and get it over with:

In this life I have heard your promise I am ready to die I have served

Your starved and ancient Presence O Lord I wait in my room at your Mercy.

(Collected Poems 175)

The anguish of worshipping such a Presence is provoked by the fact of its transiency. It is a mystic glimpse, and there is no certitude of its authenticity. The whole of the Universe and the concept of divinity seem to be an endless cycle of nothingness. This dilemma is clearly expressed in the poem "Laughing Gas":

An endless cycle of possibilities clashing in Nothing

With each mistake in the writing inevitable from the beginning of time

The doctor's phone number is Pilgrim $1-0000$

Are you calling me, Nothing? (Collected Poems 195) 
Ginsberg, as pilgrim, is faced with the dizzy possibilities of nothingness. This is a classic existential situation that calls for something akin to the nihilism experienced by Emily Dickinson, and the experiences of both of them can be closely linked to the Kierkegaardian "leap of faith". The poem "Magic Psalm" is also particularly intriguing because of its apparent kinship with the poems of spiritual anguish:

Drive me crazy, God I'm ready for disintegration of my mind, disgrace me in the eye of the earth,...

Descend O Light Creator \& Eater of Mankind, disrupt the world in its madness of bombs and murders... (Collected Poems 256)

As prayer, the poem directs its appeal most significantly to "Beauty invisible to my century!" (Collected Poems 256).The prayer unfolds, towards the end of the poem, into a series of specific requests that highlight Ginsberg's concern (Merrill 1988: 82):

that I surpass desire for transcendency and enter the calm water of the universe

That I ride out this wave, not drown forever in the flood of my imagination

That I not be slain thru my own insane magic... (Collected Poems 256)

The petitions outline Ginsberg's dilemma. The first petition suggests his need for peace, for the decade of pilgrimage initiated by the Blake vision has worn him down. The mad quest for the transcendent or the Divine, which was also the fate of Emily Dickinson, is seen as a destructive force within him that must be overcome. He realized that peace must be made with the universe and with existence and in this case one can easily relate his attempt to the main thought behind existential philosophy. "The Reply", a companion piece to "Magic Psalm", is a poem in which Ginsberg presents himself as a man confronting death. His emotions are poetically transcribed into the opening line of the poem as "God answers with my doom!" (Collected Poems 257). As in most experiences of fear, the triggering ingredient is the unknown:

I am a Seraph and I know not wither I go into the Void

I am a man and I know not wither I go into Death -

Christ Christ poor hopeless

Lifted on the Cross between Dimension -

To see the Ever- Unknowable!. (Collected Poems 257)

Being unable to attain peace he almost immediately like Dickinson, identifies his experience with Christ who has almost shared his hopeless feeling of being "lifted on the Cross between Dimension" (Collected Poems 257). Faced with such a dead end, it is inevitable that consolation must come from within and the concluding poem of the volume, appropriately titled "The End", seems to herald this message. At this point Ginsberg paints a picture of humanistic bravado of one challenging the faceless Destroyer and taking life as it comes: "I receive all, I'll die of cancer, I enter the coffin forever/ I close my eye, I disappear" (Collected Poems 259)

These poems further lead on to poems like "Mescaline" and "Lysergic Acid", in which Ginsberg raises the same kind of questions regarding God and the concept of heaven:

What Happens when the death gong hits rotting Ginsberg on the head

What universe do I enter

Death death death death death the cat's at rest

$\ldots$

Thank you, O lord, beyond my eye

The path must lead somewhere. (Collected Poems 228)

One of Ginsberg's poems, later published in Empty Mirror, was based on a real dream about "a classic hooded figure" and it had a mysterious title "The Shrouded Stranger". Thus inspired, the poem not only seems to prefigure a more than fifteen - year- long search for the hidden divinity, but to anticipate some of its ultimate fulfilment:

I dreamed I was dreaming again

And decided to go down the years

Looking for the Shrouded Stranger

$\ldots$

I'll bet you didn't think

It was me after all," he said. (Collected Poems 47 - 48)

But before Ginsberg could fulfil his dream prophecy and face the "Shrouded Stranger" in real life, he had to subject himself to the rituals of self- destruction and learn to accept his bodily self (Hyde 1984: 439). Only then could he realize that existence itself was God. The change that had come about in Ginsberg's thought, after his commitment to Buddhism was a distinct deviation from his previous position and thought process. Ginsberg describes it in the following manner: "I suddenly didn't want to be dominated by that non - human any more, or even be dominated by the moral obligation to enlarge my consciousness any more...I was suddenly free to love myself again, and therefore love people around me, in the form that they already were. And love myself in my own form as I am" (Clark 1966: 49-50). 


\section{Conclusion}

Like the transcendentalists who inspired them, both Ginsberg and Dickinson were critics of "corpsecold" orthodoxies; they were champions of spiritual experience over theological formulations and in order to express their viewpoints they conjured out of inherited and imported materials a new religious vision. What is truly important in this paper is a desire to convey to its readers a startling similarity in the thought-process and the quest of two poets who were not only separated by almost a century, but also belonged to different gender groups. Ginsberg had a vision haunted mind which he deliberately used in order to transcend reality. Ginsberg was also one of the first to insist that the Beat Generation is a religious phenomenon and that Beats depend on constant revelations and mystic visions. They were great supporters of the Zen lunatics and discovered a spirit of oneness with them. The scope of this paper is limited to a discussion on the similar ideas that both Dickinson and Ginsberg shared about the divine figure but the discussion could be further extended by tracing out a similarity between their ideas regarding the concept of 'madness'. It would be found that Dickinson who wrote, "Much Madness is divinest Sense" thought no differently about the concept of 'madness' from Ginsberg, or for that matter the Zen lunatics or even William Blake (The Poems of Emily Dickinson 278). One could easily take this study forward to explore new dimensions in these areas. Both Dickinson and Ginsberg were nonconformists who did not agree to take anything without questioning and bravely flouted the age old conventions in order to inspire people to think differently. Like Thoreau, they insisted on the sanctity of everyday life and the sainthood of the nonconformist. Hence, in 1963, Ginsberg adds the comment on the flyleaf of Kaddish: "the key to life found at last in our self".

\section{References}

[1]. Charles Churchyard, National Lies: The Truth about American values, American Individualism and Emerson, Its Champion, 27 October 2012. <http://www.charleschurchyard.com/emerson.html>.

[2]. Ralph Waldo Emerson, and Peter Norberg, Essays and Poems by Ralph Waldo Emerson, Barnes \& Noble Classics (New York: Spark Educational Publishing, 2005).

[3]. Paul P Reuben, Chapter 4: Emily Dickinson, PAL: Perspectives in American Literature-A Research and Reference Guide, 22 March 2014.<http://web.csustan.edu/english/reuben/pal/chap4/dickinson.html>.

[4]. Feross Aboukhadijeh, Transcendentalism, Religion, and Utopian Movements, StudyNotes.org. Study Notes, Inc., 17 Nov. 2012.19 March 2014.<//www.apstudynotes.org/us-history/topics/transcendentalism-religion-and-utopian-movements/>.

[5]. Emily Dickinson, The Poems of Emily Dickinson (Ed.), Thomas Johnson, 3 vols, Cambridge, Mass.: Harvard University Press, $1951,1955$.

[6]. Albert Gelpi, Emily Dickinson: The Mind of the Poet (Cambridge: Harvard University Press, 1965).

[7]. Cynthia Griffin Wolff, Emily Dickinson (New York: Addison - Wesley Co., 1988).

[8]. Emily Dickinson, The Letters of Emily Dickinson (Ed.), Thomas H. Johnson and Theodora Ward, 3 vols, Cambridge, Mass.: Harvard University Press, 1986.

[9]. Charles R. Anderson, Emily Dickinson's Poetry: Stairway of Surprise (New York: Holt, Rinehart and Winston, 1960).

[10]. Walter Kaufmann, Existentialism: From Dostoevsky to Sartre (New York: Penguin Group (USA) Inc., 1975).

[11]. Judith Farr, Emily Dickinson: A Collection of Critical Essays (New York: Prentice Hall, 1995).

[12]. Helen McNeil, Emily Dickinson (New York: Pantheon Books, 1986).

[13]. Roger Lundin, Emily Dickinson and the Art of Belief (Michigan: Wm. B. Eerdmans Publishing, 2004).

[14]. Neeru Tandon, and Anjana Trevedi, Thematic Patterns of Emily Dickinson's Poetry (New Delhi: Atlantic Publishers \&Dist., 2008).

[15]. Mario L D’Avanzo, Dickinson's 'The Reticent Volcano' and Emerson, American Transcendental Quarterly, No. 14 (Spring 1972): $11-13$.

[16]. Harold Bloom, Emily Dickinson: Bloom's modern critical views (New York: InfoBase Publishing, 2008).

[17]. Seymour Krim, The beats: a Gold medal anthology (Minnesota: Fawcett Publications, 1960).

[18]. Carl. T. Jackson, The counterculture looks east: beat writers and Asian religion, American Studies 29: 1(Spring 1988) 51-70.

[19]. Stephen Prothero, On the Holy Road: The Beat Movement as Spiritual Protest. The Harvard Theological Review 84: 2 (April 1991): 205-222. JSTOR, 29 October2012.

[20]. Thomas Clark, The Art of Poetry VIII, Paris Review37 (Spring 1966): 38 - 39.

[21]. Allen Ginsberg, Collected Poems 1947 - 1980(New York: Harper \& Row, 2006).

[22]. Thomas F Merrill, Allen Ginsberg, Revised Edition (Boston: Twayne Publishers, 1988).

[23]. Lewis Hyde (Ed.), On the Poetry of Allen Ginsberg (Ann Arbour: The University of Michigan Press, 1984). 